\title{
iRAKER: UPV/EHUko irakasleen gaitasun akademikoa garatzeko programa. Lehen deialdiaren inpaktuaren balorazioa
}

\author{
Aitor Mendia-Urrutia eta Itziar Rekalde-Rodriguez* \\ Euskal Herriko Unibertsitateko ikertzailea, *Euskal Herriko Unibertsitateko irakaslea
}

Ikerketa kualitatibo honetan iRAKERek, UPV/EHUko irakasleen gaitasun akademikoa garatzeko programak, bertan parte hartutako irakasleen irakaskuntza-, ikerkuntza- eta kudeaketa-gaitasunean izan duen inpaktua aztertu da. iRAKERen lehen deialdian parte hartutako irakasleen esperientzia sakonean ezagutu nahi zela kontuan izanik, kasu-azterketa bat gauzatu da. Horretarako, datuak biltzeko estrategia nagusia sakoneko elkarrizketa izan da, bertatik eratorritako datuak galdetegietatik eta dokumentuen analisi hermeneutikotik eskuratutakoekin triangelatu badira ere. Horrela, irakasleen motibazioak, eskuratu dituzten gaitasunak eta horiengan izandako eraldaketak ezagutu ahal izan dira. Ondoriotzat esan liteke programa honek bertan parte hartutako irakasleen ikerkuntza- eta kudeaketa-gaitasunean eragina izan duela, baina batez ere haien irakaskuntza-gaitasunean.

GAKO-HITZAK: Goi-mailako hezkuntza · Irakasle hasiberriak · Mentoretza · Kasu-azterketa $\cdot$ Garapen akademikoa.

\section{iRAKER: Programme for the development of the academic competence of UPV/EHU teaching staff. Assessment of the impact of the first call}

The aim of this qualitative research is to investigate the impact of iRAKER, a program intended to develop the academic abilities of UPV/EHU teachers, in the teaching, managing and investigating abilities of those who have taken part on it. In order to do that, a case study was carried out, as we wanted to deeply research the case of the teachers who have taken part in the first call organised by iRAKER. In that case study, conversations were used in order to collect data. The data collected in those conversations has been completed by triangulation, by means of hermeneutic analysis of questionnaires and documents. In this way, it has been possible to know the motivations of the teachers, the acquired competencies and the changes that have taken place in them. Finally, as a conclusion, it could be said that this program has impacted on management and investigation abilities of those teachers who took part on it. But mostly, it impacted on their teaching abilities.

KEY WORDS: Higher Education · Beginning Teachers · Mentoring · Case Study · Academic Development. 


\section{Sarrera}

Goi-mailako hezkuntzaren testuinguruan erreforma eta aldaketaz beteriko errealitatea topa daiteke. Egoera horrek espektatiba-proiekzio eta ezinegon ugari sortzen du eta, ondorioz, eztabaida ugari azaleratu dira. Eztabaida horien erdian, nola ez, unibertsitateko irakasleak kokatzen dira, bai eta haien prestakuntza espezifikoaren beharra ere (Margalef eta Álvarez, 2005; Paricio, Fernández eta Fernández, 2019).

Testuinguru hori ikusirik, hainbat unibertsitatetako errektoreordetzek unibertsitateetako irakasleei eskaintzen zieten prestakuntza mota aldatu dute. Ondorioz, konturatu dira jada ez dela nahikoa ohiko kurtso edo seminarioak eskaintzea, eta horren ordez prestakuntza-programa zabal eta konplexuagoak bultzatzen hasi dira (Margalef eta Álvarez, 2005; Mas, 2011).

Kontuan izan behar da, egun, ez dela nahikoa irakasleak bere irakasgaiko materia ezagutzea. Horren ordez, hainbat gaitasun eskuratu behar ditu derrigor eta, besteak beste, nola irakatsi eta zer jarrera izan ezagutu behar du (Fernández eta Paricio, 2019). Ondorioz, ikus daiteke ezinbestekoa dela konpetentzietan oinarritutako prestakuntza jasotzea; jada ez baitago prestakuntza profesionalaren eta prestakuntza zientifiko-akademikoaren arteko banaketa argirik (Álvarez, Romero, Gil, Rodríguez, Clares, Asensio, del Frago, García, García, González, Guardia, López, Rodríguez eta Salmeron, 2011).

Azken finean, goi-mailako hezkuntza jasaten ari den eraldaketa hau era global batean ulertu behar da eta ezin da ukatu irakaskuntza moldeak ere eraldatzen ari direla. Eraldaketa horren eskutik dator ohikoak diren edo izan diren klase magistralen amaiera nonahiko irakaskuntza-ikaskuntza estrategia gisa, eta modu zabalagoan, irakasleen funtzioa ikasleen bidelagun izatea dela ulertu behar da, azken horiek ikas dezaten tresnak eskainiko dituen figura (Fernández eta Paricio, 2019; Lobato eta Guerra, 2016).

\section{Marko teorikoa}

\subsection{Kalitatezko hezkuntza eta etengabeko prestakuntza unibertsitatean}

Irakaskuntza molde berriez eta goi-mailako hezkuntzaren eraldaketez hitz egiteko, ordea, ezinbestekoa da kalitateaz hitz egitea. Hala ere, kalitatea denek berdin ulertzen ez duten kontzeptu bat dela ere garbi izan behar da. Ospinarentzat (2011), goi-mailako hezkuntzaren kalitatea helburu instituzionalak lortzean datza. Horrek berekin dakarren erronka da unibertsitate bakoitzak bere helburuak dituela, batzuentzat helburu horiekin kalitatea lortuz eta beste batzuentzat ez. Alabaina, autore horrek kalitatea ulertzeko era guztietan komunean dagoen kontzeptu bat identifikatzen du, etengabeko prestakuntza, hain zuzen ere, horrela soilik lor baitaitezke aldakorrak diren helburuak.

Hori dela-eta, agerikoa da etengabeko prestakuntza kalitatea lortzeko baldintza ezinbestekoa izatea. Hots, hezkuntza-erakundeen plangintza, antolakuntza eta 
funtzionamendu egokia bermatzeko, nahitaez kontuan izan behar da giza faktorea, bai eta hori eguneratua egotea ere (Dimitrescu, Sârbu eta Lacroixl, 2014).

Etengabeko prestakuntza erakunde baten barruan egiten den kasuetan, bertako langileei zuzendua egongo da. Prestakuntza honen zeregina langile horiek lanerako dituzten gaitasunak hobetzean datza, eta, horrela, erakunde horrek jasan dituen edo jasango dituen aldaketetara moldatzea. Honenbestez, etengabeko prestakuntzaprogramak espezializazio-maila altuagoetara bideratuta egoten dira (Jornet, Suárez eta Perales, 2000). Aurrez esan bezala, bikaintasuna erakundeen helburuen araberakoa da eta helburu horiek aldakorrak diren heinean, langileak eguneratuak egotea ezinbestekoa izango da helburu horiei erantzun eta goi-mailako hezkuntzaren bikaintasuna lortzeko.

\subsection{Unibertsitateko irakasleen etengabeko prestakuntza}

Behin gaur egungo goi-mailako hezkuntzaren testuingurua ikusirik, irakasleen prestakuntza ere balioan jarri behar da egoera hori hobetuz bikaintasuna lortzeko. Izan ere, erakundearen kalitatea bilatzeko, ikasleen ikaskuntza-prozesuak hobetu behar direla ulertuz gero, ezinbestekoa da hobekuntzaren ardatza unibertsitateko irakasleen ahalduntze, berritze eta prestakuntzan jartzea (Madinabeitia eta Fernández, 2017).

Gai hau jorratzen hasi aurretik, ulertu behar da goi-mailako hezkuntzako irakasleen jarduera ezin dela era bakar batean ulertu. Izan ere, irakasle izateak ezkutuko hainbat gaitasun ditu, aldakorrak direnak eta testuingurura moldatu behar direnak. Ezagutza horiek ezagutza kognitiboak, prozedurazkoak edo jarrerazkoak izan daitezke, eta ezagutza horiek guztiek kultura profesionala eratzen dute (Bozu, 2010; Tardif, 2004).

Prestakuntzaren ildoari jarraituz, Madinabeitiak eta Fernándezek (2017) dioten bezala, marko honetan nagusitu den etengabeko prestakuntza ulertzeko erak bi ezaugarri nagusi ditu. Alde batetik, irakaskuntza-ikaskuntza prozesuen inguruko prestakuntza erdigunean kokatzen du, eta, bestetik, unibertsitatea ikasten duen erakunde bezala ulertzen du. Honenbestez, ondoriozta daiteke unibertsitatea ikasleentzat ez ezik, irakasleentzat ere prestakuntza-eremu bezala ulertzen dela (Fernández eta Rekalde, 2011).

Hariari tiraka, irakasleak bere ikasketa-prozesuan zehar irakaskuntzari buruzko hainbat aurreiritzi sortuz joaten dira, haien esperientzian oinarrituz. Noski, esperientzia hutsak ematen duen ezagutza ez da nahikoa eta unibertsitateetan jasotzen den prestakuntzak ez du aurreiritzi horiek puskatzea lortzen (Marcelo, 2008). Bada, autore horrek babesten duenez, lanean ari den bitartean prestakuntzaprozesuak aurrera jarraitzea ezinbestekoa da, une horretan lor baitaiteke irakaslea bere errealitatearekin lotuz prestakuntza osoago bat lortzea.

Izan ere, irakasle bat bere lanpostuan hasten den unean, ilusio bezainbeste kezkarekin hasten da. Beraz, jasotako prestakuntza aplikatu nahi izaten du, nahiz eta horretarako tresna nahikorik izan ez. Horrez gain, esperientzia pertsonalean 
bizi izandakoa erreproduzitzeko joera ere izaten du eta horri guztiari bere zeregin berri guztiak betetzeko beldurra gehituz gero, etengabeko prestakuntzaren beharra ukaezina da. Gainera, prozesu hori bakarrik egin behar izaten dute, inoren jarraipenik jaso gabe, irakasle hasiberriaren egoera are gehiago zailduz (Vélaz de Medrano, 2009).

\subsection{Irakasle hasiberrien prestakuntza goi-mailako hezkuntzan}

Orain arte prestakuntzaren inguruan zerbait argi gelditu bada, zera da: etengabe gauzatzen den prozesu bat dela. Horrekin batera, kalitatea bilatzeko eta eraldaketen aurrean prest egoteko ezinbesteko praktika dela ere argi geratu da. Fernándezek (2008) dioenez, ordea, irakasle hasiberriengan are garrantzitsuagoa da prestakuntza. Izan ere, haren aburuz, irakasle berri oro testuingurura egokitu behar da ahalik eta era egokienean; izan ere, hasieratik bere lana gauzatzeko estrategiak bereganatuz gero, zoriontsuagoa izango da lanari dagokionez eta aukera gehiago egongo da etorkizunean profesional ona izateko.

Irakasle hasiberrien prestakuntzak are garrantzi gehiago hartzen du kontuan izanez gero, Sánchezek eta Mayorek (2006) diotenaren arabera, egun Espainiako Estatuko unibertsitateetan hasten diren irakasleen ezagutza pedagogikoa nahiko mugatua dela. Diotenez, irakasle horiek, haien arloetako diziplinari dagokionez, oso ongi formatuak egon ohi dira; aldiz, ez dute ezagutza horiek transferitzen jakiten. Hori kontuan izanik, bi autore horiek egoera horren aurrean prestakuntza-programak ezartzea proposatzen dute; ez, ordea, edozein eratako programak, baldintza hauek betetzen dituztenak baizik:

- Parte-hartzeak borondatezkoa behar du izan, baina ez indibiduala.

- Pizgarri intelektual, emozional eta sozialak kontuan izan behar dira. Irakasleek ikerkuntza-, irakaskuntza- eta gestio-arloetan hobekuntzaprozesuak abian jar ditzaten arrazoiak aurkeztu behar zaizkie.

- Testuinguruan garatu behar dute programa irakasle hasiberriek, eta mentoreak haien ezagutza-arlo berekoa izan behar du.

- Hobekuntzek irakasleari, irakasle taldeari, departamentuari eta unibertsitateari zuzenduak egon behar dute.

- Klima egokia sortu behar da.

- Prestakuntzak eta hausnarketak lotuta egon behar dute.

Azken finean Fernándezek (2003) dioenarekin bat, arlo bakoitzeko ezagutza handiak ez ezik, ezagutza horiek era egokian helarazteko eta zabaltzeko gaitasuna ere izango duen irakasleak, bere buruari ez ezik, gizarte guztiari ere on egingo dio.

\subsection{Mentoretza: irakasleen prestakuntzarako estrategia}

Orain arte aipatutako ezaugarriak garrantzitsuak badira ere, ezinbestean estrategia sistematizatuak abian jartzea lortu behar da, eta horretarako, mentoretzaprogramak guztiz baliagarriak dira. Hain zuzen ere, formatutako eta konprometitutako 
mentoreen bidez soilik lor baitaiteke irakasleei lan-ibilbideko lehen urteetan benetako prestakuntza eskaintzea (Vonk, 1996).

Zentzu berean, Smith-ek eta Ingersoll-ek (2004) diote irakasle hasiberriak, sarri, bakarrik utzi ohi direla haien lanpostuetara heltzean. Horrek galduta daudelako sentsazioa sorraraz diezaieke eta hori ekiditeko era aproposa izan liteke esperientzia gehiago duen lankide baten laguntza sistematikoa jasotzea.

Hala ere, autore horiek diotenez, irakasle hasiberriei eskaintzen zaizkien laguntza-programa guztiak ez dira berdinak, eta kontuan izan behar da, esaterako, haien iraupena, mentoreek aurrez prestakuntzarik jaso ote duten edo mentorizatuentzat prestakuntza espezifikorik eskaintzen ote den. Haatik, ikerketa horretan, programaren arrakastan eragin handia duen faktore bat topatu dute. Izan ere, mentorea mentorizatuaren ezagutza-arlo berberean kokatzen bada, aukera gehiago egongo da mentoretza-prozesua aberasgarria izateko (Smith eta Ingersoll, 2004).

Unibertsitateen ezaugarri nagusietakoak haien konplexutasuna eta etengabeko aldaketarako joerak dira (Herrera eta Mohamed, 2014), eta hori ere kontuan izan behar da mentoretza-programak aplikatzeko garaian. Izan ere, bertan lan egiten duten irakasleek irakaskuntza-ikaskuntza prozesu esanguratsuak jarri behar dituzte praktikan, eta normalean, Espainiako Estatuaren kasuan behintzat, irakasle hasiberriek ez dute zeregin horiek gauzatzeko nahikoa prestakuntza jasotzen (Herrera, Fernández, Caballero eta Trujillo, 2011). Egoera horri irtenbidea emateko era aproposa da mentoretza-prozesuak abian jartzea (Herrera eta Mohamed, 2014; Herrera, Fernández, Caballero eta Trujillo, 2011).

Honenbestez, mentoretza-prozesu emankorren uzta izan ohi da irakasle hasiberriek unibertsitatean dagokien tokia bilatzea eta gauzatu behar dituzten zereginetara egokitzen joatea (Conde eta Martín, 2016).

\section{Testuinguru enpirikoa}

UPV/EHUren kasuan, aurreko ataletan ikusi diren beharrei erantzunez eta egoerari irtenbide sistematizatu bat emateko asmoarekin, Irakasleen Gaitasun Akademikoa Garatzeko iRAKER programa jarri da abian. Unibertsitateak bere irakasleikertzaileen premiei erantzuna emateko estrategia sendoen beharra identifikatu du, batez ere, irakasle-belaunaldi berriei dagokienez. Izan ere, unibertsitate honetan, lehen aldiz, belaunaldi-aldaketa gerturatzen ari da. Beraz, irakasle berriei ez ezik, ikastegi, sail eta unibertsitateari berari ere eragingo dien testuinguru berria sumatzen da epe laburrean. Hortaz, egoera horri erantzuna emateko sortutako programa da iRAKER, unibertsitateko irakasleek garatu behar dituzten hiru arloetan zentratuz: irakaskuntza, ikerketa eta konpromiso publikoa (SAE/HELAZ, 2018), eta betiere unibertsitateak duen IKD (Ikaskuntza Kooperatiboa eta Dinamikoa) hezkuntzaereduari jarraituz (Alkorta, 2019). iRAKER programa Hezkuntzarako Laguntza Zerbitzuaren (SAE/HELAZ) eta ikerkuntzarako zerbitzu orokorren (SGIker) eskutik iristen da irakasleengana. 


\section{1. iRAKER programa. Helburuak}

Hori guztia kontuan izanik, honako hauek dira programak dituen helburuak (SAE/ HELAZ, 2018: 3):

- Laguntza ematea finkatze-bidean dauden irakasle doktoreei UPV/EHUko irakasle izateko nortasun profesionala bere osotasunean eraikitzeko eta plantilla egonkorrean finkatzeko.

- Irakasle doktore akreditatu hasiberrienak unibertsitatearen dinamika konplexuan sartzea (irakaskuntza, ikerketa eta konpromiso publikoa), lan horretan irakasle berriak eta finkatuak tartean sartuz.

- Erraztasuna ematea talde honek UPV/EHUko Irakaskuntza Profesionaleko Plana diseinatu eta betetzeko behar duen laguntza-prozesurako, kontuan izanda abiapuntu izango dutela beren esperientzia, eta helmuga, hurrengo akreditazioak ezartzen dizkien erronkak.

- UPV/EHUko ikastegiei eta sailei ardurak ematea lan horretan, hasiberriak irakasle taldeen, ikertaldeen eta erakundeari laguntza emateko lanaren dinamikan sar daitezela bultza dezaten.

- Baldintza egokiak sortzea talde hau Unibasq agentziaren bidez kanpoko akreditazioa lortzea bideratzeko.

\subsection{Partaideak}

Programa osatzen duten taldeez hitz egiteko, alde batetik, programaren arduradunak izango diren koordinazio-taldekideak aipatu behar dira. Horiek, iRAKER diseinatzeaz, gestionatzeaz, programaren ebaluazioa egiteaz eta programa birbideratzeaz arduratzen dira. Bestetik, mentore-sare batek hartzen du parte. Horiek, UPV/EHUko irakasleak dira eta programako parte-hartzaileen gidaritza-lana egiten dute. Garrantzitsua da, halaber, programaren parte-hartzaileak aipatzea, haiek izango baitira prozesuaren ardatz. Azkenik, hautaketa- eta erreklamaziobatzordea dago; hautatze-prozesuan sortutako balizko erreklamazioak ebazten dituen taldea (SAE/HELAZ, 2018).

Programaren parte-hartzaileak hautatzeko, kontuan hartzen dira norbanako bakoitzak aurrez izan duen ibilbide profesionala, hizkuntza-gaitasuna, erakundearen testuingurua eta garapen profesionalarekin loturiko gaiak. Edozein kasutan ere, badaude parte-hartzaile guztiek derrigor bete beharreko baldintzak. Izan ere, prestakuntza hau irakasle atxiki doktoreei dago zuzendua, unibertsitatean irakaslelanean urtebete baino gehiago eta 5 urte baino gutxiago eraman behar dute, arduraldi osoko kontratua izan behar dute eta irakaskuntza esleitua izan behar dute 2017/2018 ikasturteko graduetan (SAE/HELAZh).

\subsection{Faseak}

Programa honek 8 ECTS kredituko lan-zama du eta 18 hilabete irauten du; epe hori hiru fasetan banatuz. Lehenengo fasean, arlo akademikoaren diagnosia 
egiten da, bai eta UPV/EHUn ikaskuntza profesionalerako duten plan proiektiboa ere. Fase honetan, parte-hartzaileek aurrez izandako esperientziak eta aurrez izan dituzten ikerketarekin eta irakaskuntzarekin loturiko emaitzak aztertzen dira. Horrez gain, bakoitzaren premiak ere identifikatzen dira eta Ikaskuntza Profesionalerako Planaren (IPP) inguruan pentsatzen hasten da (SAE/HELAZ, 2018).

Bigarren fasea IPP garatzen hasteko lehen etapa da. Fase honetan, mentoreek laguntza eskaintzen diete parte-hartzaileei eta bien artean IPP kontrastatzen dute. Horrez gain, prestakuntza-tailerrak egiten dira eta Docentiaz ebaluazio-programa osatzeko prestatzen dira. Azkenik, ikerketa-lanerako prestakuntza ere eskaintzen zaie (SAE/HELAZ, 2018).

Azkenik, hirugarren fasean, norbanako bakoitzarentzat ibilbideak garatzen dira. Oraingo fase honetan ere, mentoreen laguntza izaten dute, IPPren jarraipena egiten dute mentoreekin batera eta prestakuntza-tailer gehiago egiten dira. Azkenik, akreditaziorako irakaskuntza-programak prestatzen dira. Aipatu behar da ere partehartzaileek prestakuntza-prozesuaren ebidentziak adierazten dituen portafolio akademiko bat osatu behar izaten dutela prozesu guztian zehar (SAE/HELAZ, 2018).

Programaren fase bakoitzean mentoreek txosten bat igortzen dute; bertan, balorazioa positiboa edo negatiboa izan den adieraziz. Fase guztietan balorazio positiboa jasoz gero, 8 ECTS kredituko ziurtagiria jasotzen dute parte-hartzaileek.

\section{Ikerketaren helburuak}

Marko teorikoan zein testuinguru enpirikoan agertutakoa ikusirik, UPV/EHUko irakasle hasiberriek iRAKER programaren baitan jasotzen duten prestakuntza era sakon batean ulertzeko beharra nabaritu dugu. Hau da, programak dituen helburu formatiboak errealitatean betetzen diren eta programan parte hartzen dutenek dituzten beharrizanak asebetetzen ote diren ezagutzeko beharra sentitu dugu. Behar horretatik abiatuta, honako ikerketa-helburuak zehaztu ziren:

\subsection{Helburu orokorra}

iRAKER programak bertan parte hartutako irakasleen irakaskuntza-, ikerkuntzaeta kudeaketa-gaitasunean izan duen inpaktua aztertzea.

\subsection{Helburu espezifikoak}

- Irakasleei iRAKER programan parte hartzeak nortasun profesionala eraikitzen lagundu dien ezagutzea.

- Irakasleei iRAKER programan parte hartzeak unibertsitatearen dinamikara egokitzen lagundu dien aztertzea.

- iRAKER programan parte hartu duten irakasleek ardura akademiko berriak hartu dituzten ezagutzea. 


\section{Metodologia}

Quecedok eta Castañok (2003) azaltzen duten moduan, metodologiak arazoak enfokatzeko eta erantzunak topatzeko erabiltzen den erari egiten dio erreferentzia. Horren arabera, ikerketa aurrera eramateko modua ere definitzen da eta metodologiaren hautaketa ikertzailearen suposizio teoriko, aurreikuspen eta helburuen araberakoa da.

Helburu horiei erantzuna eman ahal izateko, ezinbestekoa da ikerkuntzametodologia bat zehaztea; aldiz, metodologia-hautu guztien atzean ikuspegi epistemologiko bat gordetzen da (Blaxter, Huges eta Tight, 2008).

Ikerketa honen helburuetara bagoaz, argi ikusten da prozesua bera ulertzea lortu nahi dela, parte-hartzaileen euren ikuspuntutik, eta haien bilakaera nolakoa izan den ezagutu nahi dela. Prozesua ulertu nahi izate horrek, bai eta informatzaileen esperientzia kontuan hartzeak ere, ikerketa hau interpretatzailea bilakatzen du.

Argi ikusten da ikerketa hau bete-betean kabitzen dela metodologia kualitatiboaren barnean; baina are zehatzago, kasu-azterketa erabili da helburuak lortzeko bidean. Kasu-azterketaz hitz egiterakoan, osotasuna kontuan hartzen duen eta sakonki ezagutzea xede duen ikerketa mota batez hitz egiten ari gara Bujan-en (2001) esanetan.

\subsection{Datuak biltzeko teknikak}

\subsubsection{Teknika kualitatiboak}

Ikerketa hau egiteko, datuak biltzeko teknika kuantitatibo zein kualitatiboak erabili dira, informazio osoagoa eskuratu eta ondorio mamitsuagoak ateratzeko asmoz.

Datuen bilketarako ekarpen garrantzitsuetako bat gaiaren inguruan idatzitako literaturaren analisia egitea da. Horretarako, ikerketa honetan, zenbait autorek idatzitakoaz ez ezik, iRAKER programak argitaratutako txostenez ere baliatu da programaren inguruko ezagutza sakona eduki ahal izateko. Horrenbestez, literaturaren errebisio horrek gaian zentratzeko eta datu-bilketarako balio izan du.

Bertatik, programaren egitura zein helburuak ezagutzea lortu da, bai eta helburu horiek betetzeko erabiltzen diren estrategiak ere. Hori oso lagungarria izan da ikerketaren helburuak finkatzeko garaian. Hots, helburu horien asetze-mailarekin zerikusia du ikerketa honen funtsak. Bestalde, gaiaren inguruan janzteak jarraian azalduko den beste datu-bilketarako teknika osatzen lagundu du.

Izan ere, ikerketa honek badu beste datu-bilketa baterako zutabe garrantzitsu bat: sakoneko elkarrizketa, hain zuzen ere. Sakoneko elkarrizketa ikerketa kualitatiboetan orokorrean eta kasu-azterketetan konkretuki erabiltzen den ohiko baliabide bat da datuen bilketa gauzatzeko. Sakoneko elkarrizketak bi pertsonaren arteko (elkarrizketatzaile eta informazio-emaile) hartu-emanean oinarritzen dira. 
Bertan, elkarrizketatzaileak gidari eta informazioaren erregistratzailearen lana egiten du, diskurtso osatu bat lortzeko asmoarekin; horrela kasua sakonean ezagutu ahal izateko. Elkarrizketatzaileak erabiliko dituen baliabideen artean, ez da galdetegi itxirik izango, elkarrizketaren noranzkoa guztiz ez mugatzeko (Madriz, 2008).

\subsubsection{Teknika kuantitatiboak}

iRAKER programaren zuzendariak, programa abian zen bitartean, hiru galdetegi ezberdin sortu eta pasa zizkien programako parte-hartzaileei. Datuak biltzeko teknika honen bitartez, datuak era azkarrean jasotzea lortzen da, parte-hartzaileen anonimotasuna guztiz errespetatuz eta, ondorioz, ikertzaileak ikertuengan izan lezakeen eragina minimora murriztuz (Casas, Repullo eta Donado, 2003).

Galdetegiak guztira hiru izan ziren, Likert eskaladun galderak eta galdera irekiak uztartzen zituztenak. Lehendabizikoa, partaideak programa hastear zeudela pasa zitzaien, bigarrena programaren erdialdera eta azkena programa amaitu ondoren. Hala ere, datu horiek ez zeuden analizaturik eta, ondorioz, ikerketa honetan metodoen triangelukatzea gauzatzeko erabiltzea erabaki zen (Beltrián, Galitó, García. Jové eta Macarulla, 2013;Tójar, 2001).

Lehenengo galdetegia, programaren hasieran pasa zitzaien irakasle partehartzaileei. Bertan, identifikazio-datuez gain, gehienbat, parte hartzeko arrazoiaren inguruan galdetu zitzaien. Horretarako, hainbat arrazoi agertzen ziren item ezberdinetan eta 1etik 5era bitarte adostasun-maila bete zuten. Galdetegiaren bigarren zatian, beste hainbat item zeuden, non programan zehar, bai eta programari esker ere, zer lortzea espero zuten galdetzen zitzaien. Gai honen inguruan, Likert eskaladun galderak agertzeaz gain, hainbat galdera ireki ere aurkezten zitzaizkien.

Bigarren galdetegia, aldiz, programaren erdialdera pasatu zitzaien. Oraingoan, identifikazio-datuez gain, prozesuari berari buruz galdetu zitzaien. Bai haien aurrerapen-pertzepzioari buruz, bai eta mentorearekin zuten harremanari buruz ere. Lehen galdetegia bezala, hau ere Likert eskaladun galderekin hasten zen eta, ondoren, galdera irekiak egin zitzaizkien bizitako prozesuari buruz.

Azkenik, programa bukatu bezain pronto, hirugarren galdetegi bat pasa zitzaien. Galdetegi hau bigarrenaren oso antzekoa da. Bertan, bizi izandako prozesuari buruz, aurreikuspenen asebetetzearen inguruan eta mentoreari buruz galdetu zitzaien. Beste behin, galdetegia Likert eskaladun eta galdera irekidun itemez zegoen osatua.

\subsection{Ikerketaren informatzaileak eta etika-alderdiak}

Aurrez deskribatu den prozesu hori guztia aurrera eramateko, ahalik eta informazio askotarikoena eskaini ahal zuten pertsonengana jotzea erabaki zen. Hori horrela, iRAKER programan parte hartu zuten irakasleengana jo zen, haiek informazio-asetasuna eskainiko zutelakoan. Beraz, hurrengo taulan ikus daitekeen bezala, parte hartu zuten 18 irakasleetatik 12 elkarrizketatu ziren. 
1. taula. Ikerketaren informatzaileak.

\begin{tabular}{|c|l|c|l|}
\hline Irakaslea & Ezagutza-arloa & Irakaskuntza-urteak & Generoa \\
\hline I-1 & Ekonomia & 15 & Emakumea \\
\hline I-2 & Irakasle-ikasketak & 13 & Emakumea \\
\hline I-3 & Ingeniaritza & 8 & Gizona \\
\hline I-4 & Ingeniaritza & 4 & Gizona \\
\hline I-5 & Erizaintza & 11 & Gizona \\
\hline I-6 & Ingeniaritza & 5 & Emakumea \\
\hline I-7 & Medikuntza & 9 & Emakumea \\
\hline I-8 & Medikuntza & 7 & Emakumea \\
\hline I-9 & Ingeniaritza & 10 & Gizona \\
\hline I-10 & Arkitektura & 13 & Emakumea \\
\hline I-11 & Irakasle-ikasketak & 11 & Emakumea \\
\hline I-12 & Erizaintza & 15 & Gizona \\
\hline
\end{tabular}

UPV/EHUren datu pertsonalen babeserako araudi eta protokoloari jarraikiz, ikerketa honetan parte-hartzaileei datuen bilketa zertarako egiten den eta nola erabiliko diren azaldu zaie, eta horrekin batera, hasi aurretik parte-hartzailearen baimen informatua jaso da (Arregi, Barañano, Eraña, Jorge, Juaristi, Larrinaga eta Mesanza, 2008).

Aldi berean, araudi horren beraren arabera, parte-hartzaileen anonimotasuna ezinbestean bermatu behar da. Beraz, hori horrela izan dadin, ikerketa honetan irakasle bakoitzari zenbaki bat ezarri zaio. Kodifikazioan I hizkia («irakaslea» hitzaren lehen hizkia) zenbaki baten aurrean (1etik 11ra) agertuko da elkarrizketatu bakoitza identifikatu ahal izateko, baina horren anonimotasuna mantenduz (ikus 1. taula). I hizkiaren ondoan dagoen zenbakiak ez du elkarrizketatuaren ezaugarririk adierazten, erabat zoriz ezarri zaio, anonimotasuna guztiz berma dadin (Blaxter, Hughes eta Tight, 2008).

\subsection{Prozedura analitikoa}

Datuen analisia, analisi ulerkor bidez egin da. Horretarako hiru fase ezberdinetan banatu da datuen analisia: eskuratutakoa ezagutu; hau da, bildutako informazio guztian agertu diren gaiak, kontzeptuak eta proposamenak identifikatu; ondoren, lortutako informazio hori kodifikatu egin da, jasotakoa are era sakonagoan ulertu ahal izateko, eta, azkenik, kodifikatutako informazio hori jasoa izan den testuinguruan ulertu da (Taylor eta Bogdan, 1987). Datu kuantitatiboen analisia, aldiz, analisi estatistiko bidez gauzatu da, horretarako SPSS tresna informatikoaz baliatuz.

Analisi horrekin guztiarekin, emaitza mamitsuak eskuratu dira. Jarraian, emaitzak aurkeztuko dira, bi teknika ezberdinen artean eskuratutakoak elkar elikatuz; horrela, era argigarriagoan agertzen baitira, bai eta datuak biltzeko estrategia ezberdinen 
bidez gauzatutako triangelukatzea ikusi ere.

\section{Emaitzak}

\subsection{Parte-hartzaileen igurikapenak programarekiko}

Erantzunak askotarikoak izan dira gai honi dagokionez, baina zalantzarik gabe gailendu dena bat izan da: akreditazioak lortzeko bidean laguntza eskuratzea. la guztiek aipatu dute karrera profesionalean akreditazioak lortzeak duen garrantzia eta, zalantzarik gabe, bide hori errazteko asmoz aurkeztu ziren iRAKER programaren lehen deialdira.

Horrekin batera, irakasle bezala finkatu nahi dutela ere adierazi dute elkarrizketetan, eta lan-egonkortasun hori lortzeko aukera aproposa ikusi zuten programa honetan.

Hala ere, ez da hori izan eman duten arrazoi bakarra eta izan da irakasle-ikertzaile funtzioetan gaitzeko aurkeztu dela esan duenik. Zentzu horretako erantzunetan, bi ildo nagusi bereiz daitezke. Alde batetik, irakasle batzuek esan zuten beren funtzioak zein diren ezagutzeko helburuz aurkeztu zirela; hau da, nolabaiteko ibilbide profesionalaren gaineko gidaritza bat jasotzeko. Beste batzuek, aldiz, era orokorragoan erantzunez, prestakuntza jasotzeko asmoz aurkeztu zirela esan zuten:

«He sido siempre mucho de seguir formándome, y me parecía que este programa me daba una opción muy buena» (I-1).

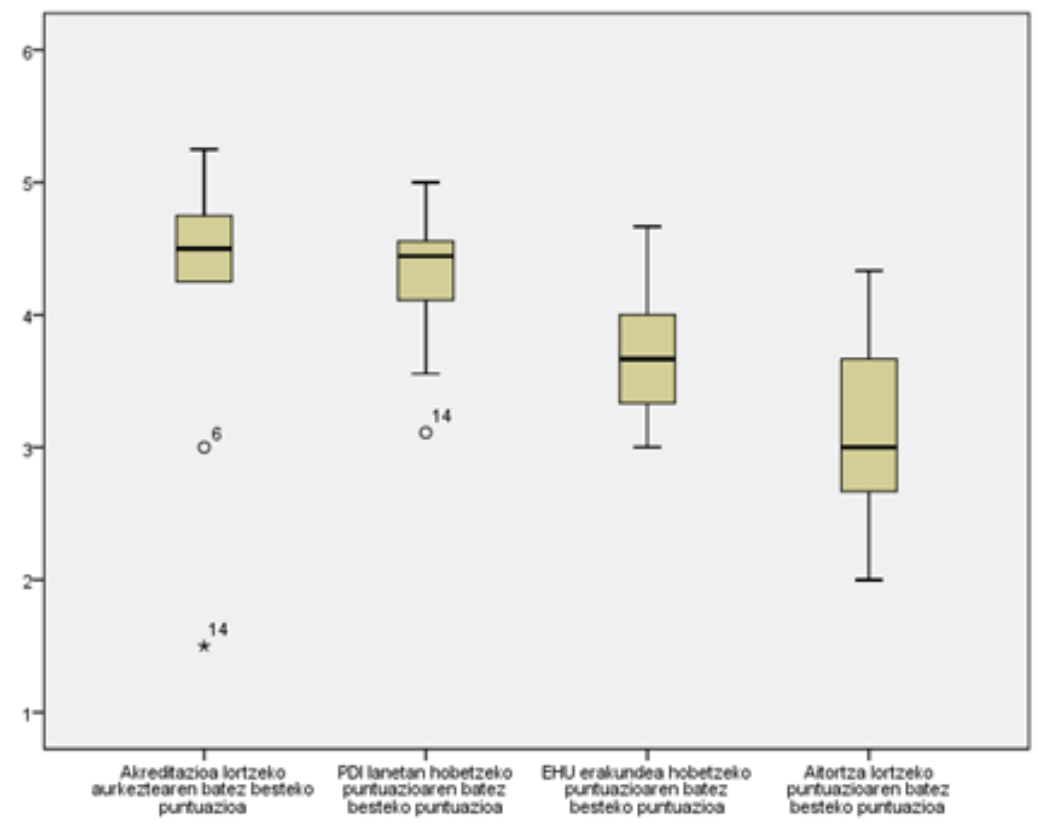

1. irudia. Aurkezteko arrazoiak. 
Datu kuantitatiboei erreparatuz gero ere, erantzunak zentzu berean bideratu dituztela ikus daiteke (ikus 1. irudia). Hots, nabaria da pisu gehien izan duen aurkezteko arrazoia akreditazioak lortzeko bidean laguntza jasotzea izan dela eta, hori, gidaritza jasotzeko nahiarekin zuzenean loturik dago.

\subsection{Mentorea}

Mentoretza programa honen zutabe garrantzitsuetako bat izanik, horren inguruan ere galdetu zitzaien parte-hartzaileei. Lehenik eta behin, mentorearen hautaketaprozesuaz hitz egitea garrantzitsua da, zeresan handia eman baitu elkarrizketetan. Horretan hasteko, aipatu behar da azkenean, guztiek egokitu zaien mentorea gustura hartu dutela, baina prozesua ez da kasu guztietan berdina izan.

Gehienetan, SAE/HELAZek proposatutako mentorea gustatu zaiela aitortu dute, edo alderantziz, haiek proposatutakoa SAE/HELAZek onartu diela. Kasu horietan, gustura agertu dira elkarrizketatuak. Beste kasu batzuetan, aldiz, prozesua ez da hain xamurra izan. Irakasle batek esan zuen berak proposatutako mentoreak ez zizkiotela onartu, eta berak ez zuela pertsona ezezagunik nahi mentoretzat. Edonola ere, negoziazioaren ondotik, berak ezagutzen zuen mentore bat izatea lortu zuen eta azkenerako gustura geratu zen.

Antzeko beste kasuren bat ere badago, guztiek aipatzen dute negoziatzeko aukera eta malgutasuna eskaintzen dituela SAE/HELAZek eta, amaierarako, denek gustura hartu zuten beren mentorea.

Azkenik, mentorearen hautaketa-prozesuarekin amaitzeko, aipatu behar da beste erantzun guztien aldean erabat ezberdina den elkarrizketatu baten kasua. Izan ere, berak aitortu zuen bere testuingurutik kanpokoa zen mentore bat izan zuela eta urruntasun hori prozesuarentzat mesedegarri izan zela:

«Hemen, inork ez du dokumenturik uzten, ez dago nori galdetu eta beraz kanpoko mentorearen figura oso ona izan da niretzat» (I-10).

Galdetegietan ere antzeman ahal izan da erlazio zuzena dagoela mentorearekiko adostasun-mailaren eta hautaketa-prozesuan izandako esperientziaren artean. Izan ere, hautatzeko prozesuarekin gustura agertu direnek puntuazio altuagoa eman diote beren mentoreari (ikus 2. taula). Jarraian ageri den taulan, aipatu berri diren hautaketa-prozesuaren eta haien mentoreei emandako puntuazioaren arteko erlazioa ikus dezakegu.

Pearsonen korrelazioak erakusten du erlazio hori. Bi aldagaien artean inongo erlaziorik egongo ez balitz, 0 puntuazioa agertuko litzateke, eta erlazioa erabatekoa balitz, 1 puntuazioa. Kasu honetan 0,636 puntuazioa lortu denez gero, bi aldagai horiek elkarren artean erlazionatuta daudela baiezta liteke. Hau da, hautaketaprozesuarekin ados dauden irakasleek beren mentoreei puntuazio altuagoa emateko joera dutela. 
2. taula. Mentoreen hautaketa eta prozesua.

\begin{tabular}{|l|l|r|r|}
\hline \multicolumn{2}{|c|}{} & $\begin{array}{c}\text { Adostasun- } \\
\text { maila mentorea } \\
\text { hautatzeko } \\
\text { prozesuarekin }\end{array}$ & $\begin{array}{c}\text { Mentorearen } \\
\text { puntuazioaren } \\
\text { batezbestekoa }\end{array}$ \\
\hline $\begin{array}{l}\text { Adostasun-maila } \\
\text { mentorea } \\
\text { hautatzeko } \\
\text { prozesuarekin }\end{array}$ & Pearsonen korrelazioa & 1 &, $636^{*}$ \\
\cline { 2 - 4 } & Sig. (bilateral) & &, 026 \\
\cline { 2 - 4 } $\begin{array}{l}\text { Mentorearen } \\
\text { puntuazioaren } \\
\text { batezbestekoa }\end{array}$ & $\mathrm{N}$ & 12 & 12 \\
\cline { 2 - 4 } & Pearsonen korrelazioa &, $636^{*}$ & 1 \\
\cline { 2 - 5 } & $\mathrm{N}$ &, 026 & 12 \\
\hline${ }^{*}$ Korrelazioa esanguratsua da 0,05 mailan. & 12 & \\
\hline
\end{tabular}

Honek beste kategoria interesgarri batera garamatza. Izan ere, elkarrizketatu gehienek aitortu dute harreman estua izan dutela; are gehiago, ia guztiek mentorea eredugarritzat dute, bai lan egiteko moduagatik, bai eta dituen ezagutzagatik ere.

«Helburu propio batzuk finkatu nahi baditut askoz hobeto bideratuko dit nire jakintza arloko pertsona batek beste inork baino ta hori oso ondo dagon gauza bat da» (I-3).

Gainera, gertutasun hori eskaintzeaz gain, programak horrenbeste lantzen ez dituen beste alderdi batzuk garatzeko figura garrantzitsutzat jo dute mentorea. Esaterako, elkarrizketatu batzuek esan dute ikerketa ez dela irakaskuntza beste lantzen programan eta, horrenbestez, mentoreek ikerketa garatzen lagundu izana oso positibotzat jotzen dute.

«lkerketaren parte hori gehiago landu dut nire mentorearekin, programako saioetan baino» (I-3).

\subsection{Programaren ezaugarri teknikoak}

Programaren ezaugarri teknikoen inguruan galdetutakoan, lehenik eta behin, iraupenaren inguruan erantzun dute elkarrizketatuek. Orokortua izan da iraupena egokia izan delako sentsazioa. Guztiek esan dute iraupena nahiko luzea dela, baina aproposa iruditu zaie luzera hori. Elkarrizketatuetako batzuek uste dute ezinbestekoa dela gutxieneko luzera hori izatea, bai ikasiak barneratua izateko tartea behar duelako, bai eta programaren hasieran norberak ezarritako helburuak lortzeko denbora behar delako ere.

«Implica un proceso de aprendizaje y de entender tu carrera que necesita de reposo» (I-7).

«Luzea da, baina horrek ahalbidetzen du zuk planteatutako helburuak lortzea» (I-3). 
Are gehiago, izan da partaiderik programak are luzeagoa izan beharko lukeela aipatu duenik, nahiz eta aitortu duten luzeegia den programa batek jendea bertara aurkeztea zaildu lezakeela.

«Gauza gehiegi tarte motzegirako. Lehen bi urteak irakaskuntza prestatzeko soilik erabiliko nituzke, eta hortik aurrera ikerketa lantzeko, baina irakaslearen egunerokotasuna oso ondo landuta izan behar da lehendabizi» (I-9).

Iraupenarekin lotuta, saiotik saiora dagoen tartea ere egokia dela aipatu dute elkarrizketatuetako batzuek, barneratua izateko beharraren ideia berarekin jarraituta. Alabaina, guztiek prestakuntza-saio berberak egin ez dituztenez, elkarrizketatu batzuek hutsune batzuk nabaritu dituzte prozesuan zehar, eta horrek programaren haria nolabait galtzera eraman ditu.

«Piska bat hori nire buruan iRAKER diluitu egin zen DOITU ez egiterakoan» (I-5).

Lan-kargari dagokionez ere erantzunak luzerari buruz hitz egitean emandakoen modukoak izan dira. Hau da, programak lan-karga handia ematen duela aitortu dute elkarrizketatu gehienek. Edozein modutan ere, lan-karga handi hori eskertu ere egin dute, baliagarri egin zaiela baitiote, eta lan-karga handi horri esker prozesua gehiago aprobetxatu dutela. Hori horrela izanik ere, izan da salbuespenik erantzunen artean. Irakasleetako batek esan zuen saio presentzialak arinegiak zirela eta haren ustez saioek praktikan erabilgarriagoa den zerbait eman beharko liekete bertaratutako irakasleei.

«Saioak beste era batera planteatu behar lirateke, non zerbait tangibleagoarekin ateratzen zaren ordu horietatik» (I-11).

Azken finean, honako ideia hau orokortu zen. Lehen modulua, jendea ezagutzeko baliagarria izan zen; bertan diziplina ezberdinetako jende ugari ezagutzeko aukera izan baitzuten. Bigarrena, elkarrizketatutako batzuek gauzatu ez bazuten ere (lehendik bertako prestakuntzak burututa zituztelako), parte hartutakoen gehiengoak baliagarritzat jo zuen eta ikasi zutela adierazi zuten. Azkenik, hirugarren moduluaren abantailarik handiena, haren izaera pertsonalizatua izan zela aipatu zen. Hala ere, egon zen modulu honek presentzialagoa izan beharko lukeela iritzi zionik.

«3. zatia presentzialagoa izatea faltan bota nuen» (I-6).

Azkenik, esan behar da, bi hobekuntza-proposamen helarazi zituztela elkarrizketetan. Alde batetik, programa hau beranduegi eskaini zaiela iritzi zioten; haien ustez, ibilbide profesionalaren hasieran jaso izan balute, baliagarriagoa suertatzeaz gain, izan dituzten hainbat buruhauste aurreztuko zituzketen.

«Oso baliagarria da hau guztia, baina askoz lehenago izan behar zuen» (I-2).

Bestetik, itxiera borobilago baten falta sumatu zen; non guztiak batu eta ikasitakoa zein norberaren ibilbidea partekatzeko aukera egongo litzatekeen.

«Agian saio bat egon liteke bukaeran, ondorioak atera eta jorratutako gaiak lantzeko» (I-5). 


\subsection{IKD eredua}

Argi geratu da IKD ereduari buruz ezberdintasun handiak daudela irakasleen artean. Bai aurre-ezagutzei dagokienez, bai programan zehar ikasitakoari dagokionez, bai eta eredu honekiko jarreraren inguruan ere. Beraz, lehenik eta behin esan behar da irakasleen artean askok IKD eredua zer zen ere ez zekitela programan sartu aurretik. Horiek esan dute programari esker IKD eredua zer den ezagutu dutela, baina eredu honekiko jarrera ez da berdina denengan.

"Sí, más que nada porque no conocía de nada el modelo IKD» (I-6).

Esaterako, irakasle batzuentzat, IKD ereduaz kontzientziatzeko lan gehiago egin behar da, haien alorretan eredu hau ez baita begi onez ikusten. Horrenbestez, kontzientziatzeko lan gehiago egin behar dela deritzote, behartzen saiatu beharrean.

«Barne motibazioa egon behar da, eta ezin da behartzean soilik pentsatu» (I-4).

Beste batzuek, aldiz, aurretik IKD eredua ezagutzen zutela esan dute. Hala ere, ezagutza hori oso azalekoa zen, eta programari esker benetan eredua zertan datzan ezagutu ahal izan dute, hainbat kasutan aplikatzeko gai izateraino.

«Entzutez ezagutzetik, ondo ezagutzera igaro naiz» (I-3).

Baina ez da horrela izan kasu guztietan. Izan ere, beste irakasle batzuek programa amaituta ere ez dute beren burua gai ikusten IKD eredua egunerokotasunera ekartzeko. Azpimarragarria da irakasle horiek garrantzi askorik ez dutela adierazi IKDrekiko.

«Ez nuke jakingo zehatz-mehatz zer den esaten jakingo, beraz ondorioztatzen dut ez dudala nire lanean oso presente eta ez dela beharrezkoa niretzat; beharko banu, landuko nuke» (I-5).

Beraz, esan liteke adostasun-maila handia egon dela IKD ereduak irakasleengan duen garrantzi txikiaren inguruan, batzuek beren buruarengan identifikatu dutelako eta beste batzuek, berriz, beren kideengan.

«Erakargarri izan liteke, baino ez dago errealitatetik hurbil» (I-10).

\subsection{Garapen profesionalaren bilakaera}

Garapen profesionalaren inguruan balorazio positiboa egin badute ere, hiru arlo nagusi bereizten dira erantzunetan, aldi berean iRAKER programaren helburuekin bat datozenak; hots, garapen profesionala irakaskuntzan, ikerkuntzan eta kudeaketa-arloan garatzen da batez ere. Hala ere, hiru esparru horietan ere badira ezberdintasun nabariak eta ezinbestekoa da bakoitza bere aldetik aztertzea.

Orokorrean, erantzunak aztertuz, argi geratzen da irakasleei haien ibilbide profesionala planeatzen eta garatzen lagundu zaiela, hobekuntza-lerroak zabalduz. Galdetegian parte hartutakoen erdiek 5eko puntuazioa eman zioten programa ibilbide profesionala planeatu eta garatzeko baliagarria izan ote zen galdetzen zuen 
galderari. Horretan laguntzeko, agian, gakorik nabarmenena hausnarketa izan da, zein helburu duten pentsatzen jarri baitute burua.

\subsubsection{Irakaskuntza}

Zalantzarik gabe ikerketa izan da gehien landu duten esparrua. Izan ere, lehendik irakaskuntza garatua zuten irakasleek, bai eta trebakuntza-behar handiagoa zutenek ere, irakaskuntza garatzen lagundu diela esan baitute. Horrez gain, esplizituki irakaskuntza dela gehien lantzen den alderdia ere esan dute elkarrizketatuek.

«Gehiago lotzen dut irakaskuntzarekin ikerkuntzarekin baino» (I-2).

Esan behar da, gehienek, irakaskuntzari buruz hausnartu dutela; hori ez ezik, irakaskuntza balioan jartzeko ere balio izan du, bai eta teoria pedagogikoak nahiz estrategia konkretuagoak eskuratzeko ere. Hori dela-eta, aipagarria da nola hainbat irakaslek konpetentziak zer diren ikasi duten, ikasle-gidaren funtzioaren berri izan duten eta metodologia aktiboei buruzko prestakuntza jaso duten. Hortaz haratago, estrategia horiek guztiak aplikatzen hasi dira programan parte hartzearen ondorioz.

«He conocido formas nuevas de utilizar metodologias activas» (I-1).

«En cuanto a metodología vamos introduciendo metodologías como el ABP que antes no utilizábamos» (I-7).

«Klasean ikasia aplikatzen saiatu naiz» (I-3).

«SAEri esker horko gauzak aplikatzera animatzen zaitu, ta gauza batzuk politak izan ziren, niretzat eta ikasleentzat» (I-4).

Hala ere, ohikoa den moduan, aldaketek ez dute ondorio onuragarririk soilik ekartzen eta esan behar da hainbat irakaslek arazoak izan dituztela programan ikasia aplikatzeko orduan. Agian, aldaketa gehiegi aldi berean txertatzearen ondorioz, irakasle batzuk ez dira guztiz eroso sentitu metodologia eta estrategia berriekin

«Incorporar todas estas metodologías implican mucho trabajo y no se pueden hacer todas a la vez, hay que ir haciendo poco a poco» (I-8).

«Para el profesorado demasiado trabajo, en la teoría estaba muy bien organizado, pero luego para corregir ha sido una locura» (I-8).

Horrez gain, esan behar da programak irakasleak bultzatu dituela haien irakaskuntzaren inguruan ikertzera. Horren adierazle da hainbat elkarrizketatuk HBP/PIE berriak eskuratu dituztela eta irakaskuntzaren inguruan ikertzeko interesa adierazi dutela. Beraz, argi ikus daiteke irakaskuntzaren inguruko interesa irakasleengan, ez soilik horren inguruan gehiago ikertzen dutelako programaren ostean, baizik eta prestakuntza gehiagotara animatu direlako.

«En esa época hice más cursos de formación» (I-6). 
Azkenik, irakaskuntzan jasandako aurrerapausoekin amaitzeko, ebaluazioa aipatu behar da. Izan ere, irakasle askok ikasleak ebaluatzeko era aldatu dutela aipatu dute. Esaterako, irakasle batzuek aipatu dute jada ez dutela nota guztia azterketa bakar batean oinarritzen. Gainera, ikasleekin duten komunikazioa hobetu ahal izan dutela ere aipatu dute, batez ere kalifikazioen eta ebaluazioen inguruan hitz egitean. $(\mathrm{I}-7)$.

«Me ha dado información, me ha dado herramientas y me ha hecho reflexionar»

Hala ere, espero zitekeen moduan irakasle denentzat ez dira berdinak izan programatik jasotako ondorioak. Beraz, argi ikus liteke adostasun-maila ez dela berdina izan denentzat. Esaterako, irakasle batek aipatu zuen saioetan zerbait praktikoagoa jasotzea espero zuela, bai eta saioetatik eskuetan zerbait izanez irtetea espero zuela.

«Nik uste nuen saioek balioko zidatela gelan egin beharrekoa lantzeko baina ez zen hori eta beraz ez zitzaidan hain baliagarria egin» (I-11).

Horrez gain, aipagarria da norbanako baten kasua; izan ere, beste guztiek ez bezala, erantzun erabat ezberdinak eman ditu. Irakasle horrek, aldaketak txertatu beharrean, irakaskuntza tradizionalago baten aldeko apustua egin du. Haren aburuz, iRAKERen ikasitakoak ez du haren testuinguruan aplikatzeko balio eta, horrenbestez, geroz eta klase magistralagoak ematen ditu eta ebaluazio-sistema ere ez du programan ikasitakoarekin bat aplikatzen.

«Esaterako ebaluazioa "tal cual" jartzen dut, eta hobeto» (I-10).

«Klase magistral gehiago ematen ditut eta geroz eta gehiago emango ditut; azterketa txiki bat nuen, eta pisu handiagoa emango diot eta uste dut ikasleek ongi hartuko dutela» (I-10).

Iritzi-aniztasun hori oso ongi biltzen da galdetegietan. Haien zereginak burutzeko errekurtsoak eskuratu dituzten galdetu zaienean, argi ikusten da guztiek ez dutela berdin pentsatzen, nahiz eta gehiengoarentzat programa zentzu horretan baliagarria izan den. Izan ere, galdetutakoen \% 66,7k 4 edo 5 erantzun du 1-5 bitarteko eskalan, 2 baino gutxiago \% 8,3k soilik erantzun duen bitartean (ikus 3 . taula).

3. taula. Errekurtsoen eskuratzea.

\begin{tabular}{|rr|r|r|r|}
\hline & & Maiztasuna & Ehunekoa & Ehuneko metatua \\
\hline Baliodun & 2,00 & 1 & 8,3 & 8,3 \\
& 3,00 & 3 & 25,0 & 33,3 \\
& 4,00 & 6 & 50,0 & 83,3 \\
& 5,00 & 2 & 16,7 & 100,0 \\
& Totala & 12 & 100,0 & \\
\hline
\end{tabular}




\subsubsection{Ikerkuntza}

Arlo hau aztertzen hasteko, lehenik eta behin aipatu behar da gehienek esan dutela programan sartu aurretik jada ikerketa landua zutela. Izan ere, egoera hori esanguratsua izan liteke hurrengo erantzunak ulertzeko. Hala ere, gehienek, programari esker gauza berriak landu dituztela aipatzen dute, batez ere, mentorearekin eginiko lanari esker.

Honenbestez, ia guztiek esan zuten ikerketa gutxiegi landu zela, denbora gehiago eskaini behar litzaiokeela eta ez dela nahikoa izan programa hau haiek ikerkuntzan trebatzeko.

«Saio bakar bat egon zen SGlker-eko bi kide etorri ziren, biometria arlokoak, eta orduan ez nuen ezer berririk ikasi ze azaldutakoa ezagutzen nuen aurretik» (I-5).

«Ez dut gogoratzen eginiko ezer, beraz, egin bagenu ere, ez zitzaidan erabilgarria egin» $(\mathrm{I}-11)$.

«SAEk irakaskuntzan laguntza eskaintzen du, baina ikerkuntzan ez, orduan ongi legoke kongresuetara joateko edo artikuluak idazteko laguntza eskaintzea» (I-5).

«lkerketan ez, batez ere dozentzian iruditu zait erabilgarria» (I-9)

Halaber, erantzun ezberdinen bat ere topa daiteke irakasleen artean eta bada ikertzeko tresna berririk jaso duela esan duen irakaslerik. Esaterako, liburutegiko zerbitzuen berri izateak ikertzeko lagundu duela esan du (I-10).

\subsubsection{Kudeaketa}

Kudeaketaren kasuan, ezberdintasun nabariak egon dira. Irakasle batzuentzat oso baliagarria izan da, eta beste batzuentzat, aldiz, ez zaio nahikoa garrantzirik eman. Bestalde, bada kudeaketa gauzatzearen alde ez dagoen irakaslerik ere.

Kasu honetan ere, irakasle batzuek esan dute kudeaketa lehendik gauzatzen zutela. Horiek izan dira, gehienbat, programaren arlo honi probetxu gutxien atera dioten irakasleak.

«Lehendik saileko idazkaria nintzen eta hortan ez dut ezer berririk hartu geroztik» $(\mathrm{I}-2)$.

Kontrako kasuetan, hau da, kudeaketarik gauzatzen ez zuten irakasleen kasuetan, erantzunak ezberdinak izan dira eta programari esker informazio berria eskuratu dutela esan dute.

«Lagundu egin dit ezagutzeko zer-nolako kudeaketa postuak existitzen diren edo zein ardura existitzen diren bertan, baina ez dut holako ardurarik hartu» (I-3).

«Me ha ayudado un montón, me ha ayudado a ver como hacen otros» (I-1).

Kasu horietan, ikasi duten arren ardura berririk hartu ez badute ere, beste kasu batzuetan programan parte hartzeari esker kudeaketa-postu berrietara hurbildu direla esan dute. Esaterako, I-4 eta I-7 programan parte hartu ondoren irakasgai bateko kudeatzaile egin dira eta l-11-k saileko idazkari izateko asmoa adierazi du. 
«Cuando entre en iRAKER ni me planteaba la gestión, me parecía que era cosa

de otros, pero ahora me han surgido oportunidades y las he aprovechado» (I-7).

Probetxuzkoa iruditu zaien irakasleek honako arlo hauek aipatu dituzte gehien: araudiari buruzko informazioa eskuratu ahal izatea eta existitzen diren kudeaketapostuen berri izatea. Horrez gain, kudeaketaren garrantziari buruzko kontzientziahartzea ere aipatu dute.

\subsection{Nortasun profesionalaren garapena}

Atal honetan aztertuko diren bi kontzeptu nagusiak nortasun profesionala eta garapena izango dira. Izan ere, irakasleek nortasun profesionalari buruz hitz egitean, enfasi handia jarri dute garapenean. Argi dago ibilbide akademikoa prozesu bat dela, eta elkarrizketatuek ere horrela ulertzen dute.

Horren adierazle da, irakasleek, ibilbide profesionalaren iragana, baina batez ere oraina eta etorkizuna enfokatu ahal izan dutela. Horrela, aitortu dute ibilbide hau planifikatzeko aukera izan dutela programan, eta garrantzi handia ematen diote aukera horri.

«Conocer lo que se espera de mí, donde estoy ahora, y que tengo que hacer para avanzar» (I-7).

«El desarrollo académico me pareció muy útil; donde estoy, que tengo que hacer, de gestión, de investigación...» (I-8).

«El aprovechamiento mayor que he sacado al programa iRAKER ha sido ser más consciente de donde estoy» (I-7).

Horrekin lotuta, irakasle bezala hobetzen lagundu diela ere esan dute. Hau da, haien funtzioen inguruan hausnartzeari esker, irakasle bezala hazi direla erantzun dute, eta bizi duten egoerara egokitzeko programa eraginkorra izan dela adierazi dute. Horretarako, espresuki irakasleen konpetentziak lantzeaz gain, pazientzia edo frustrazioari aurre egiteko gaitasuna landu dituzte, zeinak irakasle-ikertzaile izateko konpetentzia garrantzitsuak baitira haien ustez. Azken finean, esan liteke profil profesionalaren inguruan hausnartu dutela. (I-7).

«Una de las preguntas que nos hacían es, ¿qué tipo de docente quieres ser?»

Horrez gain, UPV/EHUren barnean haien tokia bilatzeko ere erabilgarria izan da programa, erantzunetan ikus daitekeenaren arabera. Hori, ziurrenik, haien funtzioaren inguruan hausnartu izanaren ondorio da, ia guztiek hausnarketa hori gauzatu baitute programan zehar (ikus 2. irudia).

«Erakundera egokitzen laguntzen du» (I-6).

«EHUra egokitzapena. Nire funtzioa eta EHU zer den ezagutzea» (I-11). 


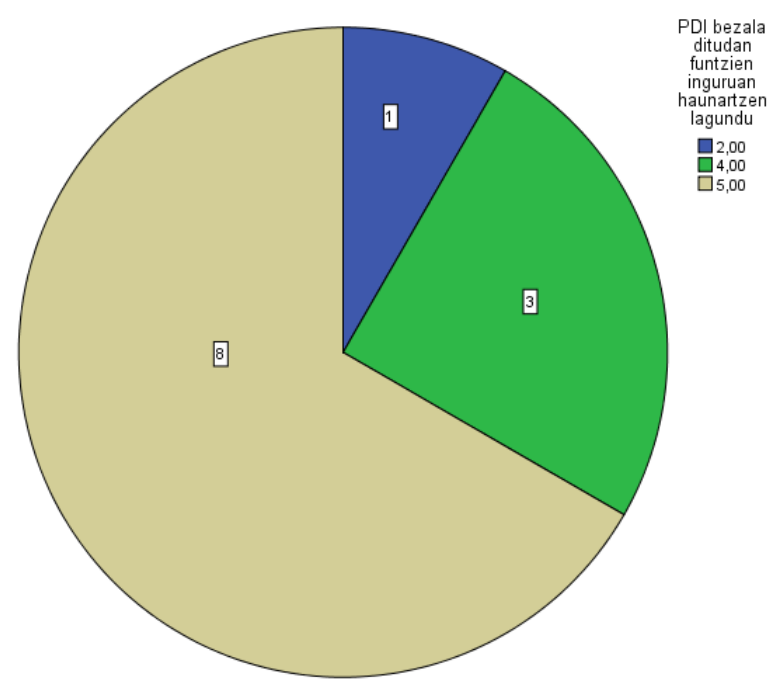

2. irudia. Irakasle-funtzioen hausnarketa.

Azken finean, esan liteke, erantzunetan ikusten denaren arabera, irakasleikertzaile izatea zer den era sakonago baten ulertzea lortu dutela parte-hartzaileetako askok programari esker. Izan ere, etorkizuna planeatzeko baliagarria izateaz gain eta erakundera egokitzen laguntzeaz gain, haien zereginak zeintzuk diren ikasi dute, bai eta zeregin horiek bete ahal izateko zer landu behar duten ere.

«Lagundu dit ulertzeko zer den irakasle izatea» (I-3).

«Irakaskuntzan klase ematearekin ez da nahiko; bueno ba metodologia aktiboetan sakontzea, irakaskuntzan gauza berriztatzaileak egitea ikasleari beste ikuspuntu bat eskaintzeko» (I-4).

\subsection{Programan eratutako harreman-sareak}

Programan eratutako harremanei buruzko erantzunak aztertzerakoan, lehendabizi topatzen den faktorerik garrantzitsuena diziplina-aniztasuna da. Izan ere, ia irakasle guztiek aipatu dituzte beste arlo batzuetako irakasleekin harremana eraikitzeak dakartzan onurak. Esaterako, aipatu dute egoera honek arazoak erlatibizatzen, enpatia izaten edo UPV/EHU bere osotasunean ezagutzen lagundu duela. Makulu bezala ere balio duela esan dute; azken finean, bakarrik ez sentitzeko eta ikuspuntu berriak topatzeko baliagarria egin zaie. Horrenbestez, bereziki esanguratsua da diziplina ezberdinetako irakasleen arteko harremana sustatzea elkarrizketatuek diotenaren arabera.

«Beste ikuspuntu batzuk ikusten dituzu» (I-2).

«Campos que, a priori, no se parecen al mío, pero que luego dan un montón de ideas» (l-1). 
«Niretzako egoera berean dagoen diziplina ezberdinetako jendearekin topo egiteak asko lasaitzen du, niretzat hori izan zen interesgarriena» (I-10).

«Conocí a gente de otras especialidades, otras facultades y te cuentan un montón de cosas que tú no sabes» (I-6).

Hala ere, diziplina ezberdinetako jendearekin ez ezik, haien testuinguruetan ere izan dute harremanak estutzeko aukera. Hori horrela, hainbat irakaslek erantzun dute haien testuinguruetan (sailak, fakultateak...) informazioa trukatzeko aukera izan dutela. Batzuek era informalean gauzatu dute trukaketa hori, eta, esaterako, programan ikasia edo burututako hausnarketak banatu dituzte egunerokotasuneko lankideekin. Beste batzuek, aldiz, irakasgaiak antolatzeko orduan, programan ikasitako kontzeptuak eraman dituzte bileretara.

«Materiala ez, baina iritziak eta hausnarketak elkarbanatzeko aukera izan dut» $(\mathrm{I}-5)$.

«Irakaskuntza gida elkarbanatu dut»(I-4).

Hala ere, esan behar da, ezagutza-arloaren arabera, eratutako harreman-sareak ere aldatu egiten direla eta testuinguru guztietan ez dutela pertzepzio berbera izan gai honi dagokionez. Galdera-ezberdintasun horiek ikusita, ezagutza-arloak eraginik izan ote zezakeen jakin nahi izan zen (ikus 4. taula). Horrela, batezbestekoen arteko konparaketa eginda hain zuzen ere, ikus daiteke osasun-zientzien arlokoek eta ingeniaritzakoek puntuazio baxuagoa eman zutela, eta, aldiz, gizarte-zientziakoek bereziki altua.

4. taula. Kontaktu-sareak ezagutza-arloka.

\begin{tabular}{|l|c|r|r|}
\hline Ezagutza-arloa & $\begin{array}{c}\text { Batezbeste- } \\
\text { koa }\end{array}$ & $\mathrm{N}$ & $\begin{array}{c}\text { Desbideratze } \\
\text { estandarra }\end{array}$ \\
\hline 1 Ingeniaritza & 3,7500 & 4 & 1,50000 \\
2 Giza Zientziak & 5,0000 & 2 &, 00000 \\
3 Osasun Zien- & 3,6000 & 5 &, 89443 \\
tziak & 4,0000 & 1 &. \\
4 Esperimentalak & 3,9167 & 12 & 1,08362 \\
\hline
\end{tabular}

Azkenik, aipagarria da, programan parte hartu duten irakasleetako batzuek «wathsapp» talde bat sortu zutela, egun oraindik ere erabiltzen dutena, eta bertan araudiari, deialdiei edo UPV/EHUk hartutako erabakiei buruz hitz egiten dute. Denek iritzi bera ez badute ere, irakasle batzuek oso tresna erabilgarritzat jotzen dute eta bertatik hainbat zalantza edo hausnarketa elkarrekin banatu dituztela esan dute.

«Duda asko plazaratu dira ta abian jarraitzen du» (I-3).

«Informazioa trukatzeko tresna bat da» (I-8). 


\subsection{Parte-hartzaileek ikasitakoa aplikatzeko izandako erresistentziak}

Guztiz erdibituta daude erantzunak kasu honetan, eta argi ikusten da ezberdintasunak nabariak direla irakasleek programan ikasia aplikatzerakoan jaso duten erantzunetan. Lehenik eta behin, ikasleen aldetik jasotako erantzunak aurkeztuko dira, eta erraz ikus daiteke erantzun guztiz ezberdinak jaso direla.

Irakasle batzuek esan dute ikasleek oso begi onez ikusten dituztela irakaskuntzaaldaketak. Metodologia berriak aplikatzean ikasleek ongi erantzuten dutela eta asko ikasten dutela.

«Kezkak sortzen dizkiete metodologia berriek baina asko ikasten dute eta asko gustatzen zaie; kuriositatea pizten die» (I-5).

«lkasleen aldetik ez, baldin eta lan karga gehiegi jartzen ez bazaie» (I-4).

Hala ere, argi bereizten da diziplinaren arabera erantzunen ezberdintasuna. Esaterako, guztiz bestelakoa izan da osasun-zientzietako irakasleek edo arkitekturakoek erantzundakoa. Esaterako, hezkuntzako graduetako irakasleek adierazi dute ikasleen aldetik erresistentziarik nabaritu ez dutela:

«Ez, magisteritzan gaude, beraz, ez» (I-11).

Eta izan ere, aurreratu berri den bezala, beste hainbat ezagutza-arlotan ikasleek ez dituzte batere begi onez hartu irakasleek txertatutako aldaketak.

«Ikasleek ez dituzte metodologia berriak nahi» (I-7).

«Proposatu diet bi astez behin kontrol txikiak egitea, eta ez dute onartu esaten dutelako lan gehiago suposatzen diela» (I-9).

«iRAKERen ikasitakoa aplikatu dut eta okerrago, ikasleek lan gehiegi egiten dutela esaten dute eta eskatzen didatena behin eta berriz da klase magistral gehiago emateko» (I-10).

Haien lankideen aldetik izan dituzten erresistentzien inguruan ere galdetu zitzaien. Eta oraingoan ere erantzunak oso ezberdinak izan ziren elkarren artean. Testuinguru batzuetan aldaketak txertatzea begi onez ikusita dagoen bitartean, beste batzuetan, ia ezinezkoa da aldaketa berririk proposatzea.

Harrera ona izan duten irakasleen artean, gehien aipatu den ideia izan da aldaketak pixkanaka egin behar direla, eta aldaketak poliki egiten badira, harrera ona izaten dutela.

«Irakasleen aldetik ere ondo, nahiz eta beste irakasle askok ez duten irakaskuntzan berritu nahi» (I-6).

«Arazoak sortzen dira bat-batean asko aldatu nahi duzunean; nik hau ulertzen dut urteetan zehar pixkanaka aldatzen joan behar den zerbait bezala» (I-4).

«Sailean ez, orokorrean aldatzearen alde» (I-2). 
Baina esan bezala, ez da hori izan egoera kasu guztietan. Izan ere, beste irakasle batzuek traba handiak izan dituzte aldaketak txertatzeko garaian; eta kasu askotan aldaketa horiek burutzea ezinezkoa suertatu zaie.

«Koordinatzaileari proposatu nizkion hainbat ekintza, aurrera eramateko aproba moduan, eta ezetza jaso nuen» (I-3).

«Sé que a parte de la gente con la que voy a trabajar les va a dar totalmente igual lo que vayamos a hacer, van a cumplir, pero no les va a gustar» (I-7).

«Cuando compartes docencia y propones nuevas actividades, son para todos, y a veces cuando son más mayores o así, pues no les hace mucha gracia y no siempre es posible» (I-8).

\section{Ondorioak}

Lehen ondorioak, zalantzarik gabe, ikerketa honen helburu orokorrarekin lotura garbia du. iRAKER irakasle hasiberrientzako prestakuntza-programak inpaktumaila altua izan du bertan parte hartutako irakasleen irakaskuntza-, ikerkuntzaeta kudeaketa-gaitasunetan, asebetetze-maila altuak, eskuratutako ezagutzek eta ezagutzen aplikazioak erakusten duten bezala. Halarik ere, aipatu behar da era garbiagoan ikus daitekeela inpaktu hori irakaskuntza-gaitasunean; nahiz eta ikerkuntza eta kudeaketan ere, orokorrean, satisfazio-maila altua, ezagutzak eskuratu izana eta horiek aplikatu izana adierazi duten.

Hala ese, esan liteke programak izandako inpaktua ez dela erabatekoa izan, testuingurua eraldatzeko ezinbestekoa baita parte-hartzaileen lankideen konpromisoa. Aldaketarako konpromiso hori, aldiz, ezagutza-arlo batzuetako kideek soilik erakutsi dute eztabaidaren azken atalean ikus daitekeen bezala. Alabaina, irakasle gehienek irakaskuntza molde berriak aplikatu izanak, eta kudeaketan ardura berriak hartu izanak, testuinguru hurbilenean zerbait aldatu dutela adierazten du.

Nortasun profesionalaren garapenean ere eragin positiboa izan duela ondorioztatu daiteke. Batez ere, kontuan izanik ibilbide akademiko/profesionalaren inguruan hausnartzeko aukera izan dutela, bai eta haien mentoreen eskutik garatu ere. Horrez gain, programak ibilbidea planifikatzeko aukera eman die; bai eta gauzatu ahal izateko zeharkako gaitasunak lantzen lagundu ere. Horri guztiari beren buruak irakasle-ikertzaile funtzioetan aztertzeko eta hausnartzeko aukera gehituta, argi ondoriozta daiteke programak nortasun profesionala eraikitzen laguntzen duela.

Aipagarria da, halaber, nola mentoreei esker, ordura arte era informal batean egiten zen unibertsitaterako egokitzapena era sistematizatu eta estrukturatu batean egin den. Horrez gain, araudia hobeto ezagutzeko aukerak ere lagundu die egokitzapen-prozesu horretan. Parte-hartzaileek programaren alderdi hau era oso positiboan baloratu izanak argi erakusten du mentoretza-programak baliagarriak direla helburu hau betetzeko. Dena dela, aipatu behar da programa ez dela guztiz hasiberriak diren irakasleekin egiten, eta parte-hartzaileek eurek esan duten bezala, komenigarria izan daiteke unibertsitatean denbora gutxiago daramaten irakasleei 
aukera zabaltzea. Horrela, hasieran irakasleek sentitzen duten desorientazioa nolabait baretu ahalko litzateke.

Ardura berrien inguruan esan daiteke positiboki eragin duela programak. Irakaskuntza-zereginetan estrategia, metodologia eta ebaluazio mota berriak aplikatu izana horren adierazle da. Are esanguratsuagoa da nola programan sartu aurretik beren burua kudeaketan ikusten ez zuten irakasle batzuek, prozesua amaitu ostean, maila txikiko kudeaketetan beren burua probatzea erabaki duten (irakasgaien koordinatzaile, esaterako). Ikerketan, aldiz, ez da hain garbi ikusten programak izandako eragina. Batez ere, irakasleek lehendik ikerketaren arloa garatuta zutela eta ikerketari saio gutxi eskaini zaizkiola adierazi dutelako. Beraz, esan liteke iRAKERek ikerketa gehiago edo era zuzenagoan landu behar lukeela, partaideek zentzu horretako ardura berriak hartzea nahiko balu.

Esanguratsua da irakasleen gehiengo zabal batek akreditazioak lortzen eta ibilbide akademikoa antolatzen lagundu diela aitortu izana. Horrek garbi erakusten du programa baliagarria dela lan-baldintza egonkorragoak lortzeko, bai eta ibilbide akademikoa burutzen laguntzeko ere. Esanguratsua da atal hau, izan ere, partehartzaileek garrantzia handia ematen zioten atal honi programan sartzeko orduan, eta, gainera, iRAKERen helburuetako bat zen.

Honek guztiak argi uzten du iRAKER programak bere helburuak lortzen dituela. Gainera, inpaktu-maila altua du parte-hartzaileengan eta, orokorrean, irakasle-ikertzaile berriak formatzeko baliagarria da hiru arlo nagusietan. Hala ere, komenigarria litzateke ikerkuntzaren eta kudeaketaren arloak gehiago lantzen jarraitzea, bi horiek ez baitira irakaskuntza bezainbeste lantzen.

Programaren ezaugarri teknikoei dagokienez ere, programa ongi antolatuta dagoela ondoriozta daiteke; bai denborari bai eta lan-kargari dagokienez ere. Azken finean, argi geratu da programaren antolaketa honi esker, bai eta mentorearen figurari esker ere, programan parte hartzen dutenen helburuak nahiz iRAKER programak dituen helburuak asebetetzen direla.

Azkenik, esan behar da komenigarria litzatekeela programak aurrera jarraitzea, eta ahal den neurrian geroz eta irakasle gehiagok bertan parte hartzea lortzea. Izan ere, irakasle gehiagori zabalduz gero prestakuntza urteetan zehar, lehen deialdi honetan sortu diren harreman-sare xumeak areagotu eta indartuko lirateke. Era horretan, pixkanaka, erakundean eragitea lortzea posible da, inpaktu-maila altuagoa lortzeraino.

Azkenik, esan behar da testuinguru guztietan ez duela eragin bera programa honek. Argi geratu da, batez ere, osasun-zientzietako eta arkitekturako irakasleek zailtasun handiak izan dituztela programan ikasia aplikatzeko orduan, eta, bereziki arkitekturan, oso zaila dela irakaskuntza eraldatuko duten harreman-sareak sortzea. Horrekin ondoriozta daiteke komenigarria litzatekeela iRAKER programa gehiago egokitzea bertan parte hartzen duen irakaslearen testuingurura, horrela irakasle horiek ikasitakoa errazago egokitu dezaten beren egunerokotasunera. 


\section{Bibliografia}

Alkorta, I. (2012): «IKD, un modelo para la educación superior en el siglo XXI», Fabrikart, 10, 14-25.

Álvarez, V.; Romero, S.; Gil, J.; Rodríguez, J.; Clares, J.; Asensio, I.; del Frago. R.; García, B.; García, M.; González, B.; Guardia, S.; Ibarra, M.; López, R.; Rodríguez, G. eta Salmerón, P. (2011): «Necesidades de formación del profesorado universitario para la adaptación de su docencia al Espacio Europeo de Educación Superior», Revista Electrónica de Investigación y Evaluación Educativa, 17(1).

Arregi, N.; Barañano, E.; Eraña, J.; Jorge, S.; Juaristi, A.; Larrinaga, A. eta Mesanza, S. (2008): Reglamento de la UPV/EHU para la protección de carácter personal, Euskal Herriko Unibertsitateko Argitalpen Zerbitzua, Bilbo.

Beltrián, E.; Galitón, N.; García, N.; Jové, G. eta Macarulla, M. (2013): «La triangulación múltiple como estrategia metodológica», Revista Iberoamericana sobre Calidad, Eficacia y Cambio en Educación, 11(4), 5-24.

Blaxter, L.; Hughes, C. eta Tight, M. (2008): Cómo se investiga, Graó, Bartzelona.

Bozu, Z. (2010): «El profesorado universitario novel: Estudio teórico de su proceso de inducción o socialización profesional», Revista Electrónica de Investigación y Docencia, 3, 55-72.

Bujan, K. (2001): "Kasu azterketa metodoaren izaera: kasu azterketa diseinua EHUko hainbat tesi lanetan", Revista de psicodidáctica, 11, 133-142.

Caballero, K. eta Bolívar, A. (2015): «El profesorado universitario como docente: hacia una identidad profesional que integre docencia e investigación», Revista de Docencia Universitaria, 13(1), 57-77.

Casas, J.; Repullo, J.R. eta Donado, J. (2003): «La encuesta como técnica de investigación. Elaboración de cuestionarios y tratamiento estadístico de los datos», Aten Primaria, 31(8), 527-538.

Dias, P.; Gomes, M.J. eta Dias, A.A. (2005): «In-service trainign: e-learning as a new and promising approach», Interactive Educational Multimedia, 11, 89-103.

Dimitrescu, M.; Sârbu, L.V. eta Lacroixl, Y. (2014): «European Trends for adults education in lifelong learning strategy: Modern Methods and romanian skills in training management», Elsevier, 180, 1.161-1.169.

Eirín, R.; García, H.M. eta Montero, L. (2009): «Profesores principiantes e iniciación profesional. Estudio exploratorio», Revista de currículum y formación del profesorado, 13(1), 101-115.

Fernández Fernández, I. eta Rekalde, I. (2011) (arg.): Ikasten duen unibertsitatea: berrikuntza eta hezkuntza aldaketa UPV/EHU-n, Euskal Herriko Unibertsitateko Argitalpen Zerbitzua, Bilbo.

Fernández March, A. (2003): «Formación pedagógica y desarrollo profesional de los profesores de universidad: Análisis de las diferentes estrategias», Revista de Educación, 331, 171-197.

(2008): «La formación inicial del profesorado universitario: el título de Especialista Universitario en Pedagogía Universitaria de la Universidad Politécnica de Valencia», Revista Interuniversitaria de Formación del Profesorado, 63(22), 161-187. 
Fernández March, A. eta Paricio, J. (2019): «Entornos de aprendizaje como espacios para la acción, interacción, autorregulación y elaboración personal del conocimiento», in J. Paricio, A. Fernández eta I. Fernández, Cartografía de la buena docencia universitaria. Un marco para el desarrollo del profesorado basado en la investigación, Narcea, Madril, 197-216.

Gijón, J. eta Crisol, E. (2012): «La internacionalización de la Educación Superior. El caso del Espacio Europeo de Educación Superior», REDU, 10(1), 389414.

González, A.I.; Araneda, N.; Hernández, J. eta Lorca, J. (2005): «Inducción profesional docente», Estudios pedagógicos XXXI, 1, 51-62.

Herrera, L.; Fernández, A.M.; Caballero, K. eta Trujillo, J.M. (2011): «Competencias docentes del profesorado novel participante en un proyecto de mentorización. Implicaciones para el desarrollo profesional universitario», Revista de currículum y formación del profesorado, 15(3), 213-241.

Herrera, L. eta Mohamed, L. (2014). «La mentorización entre el profesorado universitario junior y senior. Un proceso de aprendizaje, apoyo y enriquecimiento mutuo», INFAD, 1(6), 453-462.

Hezkuntzarako Laguntza Zerbitzua (SAE/HELAZ) (2018): iRAKER UPV/EHUko irakasleen gaitasun akademikoa garatzeko programa, <https://www.ehu. eus/eu/web/sae-helaz/iraker> (2019ko irailaren 16an kontsultatua).

(SAE/HELAZb): Irakaskuntza-metodologia aktiboak ERAGIN programan, $<$ http://www.ehu.es/eu/web/sae-helaz/eragin-irakaskuntza-metodologiaaktiboak> (2019ko irailaren 16an kontsultatua).

, (SAE/HELAZh): <https://www.ehu.eus/eu/web/sae-helaz/iraker> (2019ko urtarrilaren 23an kontsultatua).

Jornet, J.M.; Suárez, J.M. eta Perales, Mํ..J. (2000): «La evaluación de la formación ocupacional y continua», Revista de investigación educativa, 18, 521-537.

Lobato, C. eta Guerra, N. (2016): «La tutoría en la educación superior en Iberoamerica: Avances y desafíos», Educar, 52(2), 379-398.

Madinabeitia, A. eta Fernández, I. (2017): «El desarrollo docente del profesorado universitario: Análisis y sistematización del concepto», Revista Interuniversitaria de Teoría de la Educación, 29, 87-108.

Madriz, G. (2008): «La entrevista en profundidad. Dos entre-vistas y una mirada» Revista ensayo y error, 35, 137-152.

Marcelo, C. (2008): «Los comienzos en la docencia: un profesorado con buenos principios», Revista de currículum y formación del profesorado, 13(1), 1-25.

Marentic, B. (2009): «Improving the quality of teaching and learning in higher education through supporting professional development of teaching staff», Napredak, 150, 341-359.

Margalef, L. eta Álvarez, J.M. (2005): «La formación del profesorado universitario para la innovación en el marco de la integración del Espacio Europeo de Educación Superior» Revista de Educación, 337, 51-70.

Mas, O. (2011): «El profesor universitario: sus competencias y formación», Revista de currículum y formación del profesorado, 15(3), 196-211. 
Ospina, R. (2011): Evaluación de la calidad en educación superior (doktoretzatesia), Universidad Complutense de Madrid, Madril.

Paricio, J.; Fernández, A. eta Fernández, I. (2019): Cartografía de la buena docencia universitaria. Un marco para el desarrollo del profesorado basado en la investigación, Narcea, Madril.

Pineda, P. (2000): «Evaluación del impacto de la formación en las organizaciones», Educar, 27, 119-133.

Quecedo, R. eta Castaño, C. (2003): «Introducción a la metodología de investigación cualitativa", Revista de Psicodidáctica, 14, 5-40.

Sánchez, M. eta Mayor, C. (2006): «Los jóvenes profesores universitarios y su formación pedagógica. Claves y controversias», Revista de Educación, 339, 923-946.

Smith, T.M. eta Ingersoll, R.M. (2004): «What are the effects on induction and mentoring on beginning teacher turnover?», American Educational Research Journal, 41(3), 681-714.

Tardif, M. (2004): Los saberes del docente y su desarrollo profesional, Narcea, Madril.

Taylor, S.J. eta Bogdan, R. (1987): Introducción a los métodos cualitativos de investigación, Paidos, Bartzelona.

Tójar, J.C. (2001): Planificar la investigación educativa: una propuesta integrada, Fundec, Buenos Aires.

Vélaz de Medrano, C. (2009): "Competencias del profesor-mentor para el acompañamiento al profesorado principiante», Revista de currículum y formación del profesorado, 13(1), 210-229.

Vonk, J.H.C. (1996): "Conceptualizing the mentoring of beginning teachers», Speeches/Meeting Papers, <https://eric.ed.gov/?q=\%22Conceptualizi ng+the+mentoring+of+beginning+teachers\%22+Vonk\&id=ED400241> (2019ko urtarrilaren 12an kontsultatua).

Zabalza, M.A. (2003): Las competencias docentes del profesorado universitario: calidad y desarrollo profesional, Narcea, Madril. 
